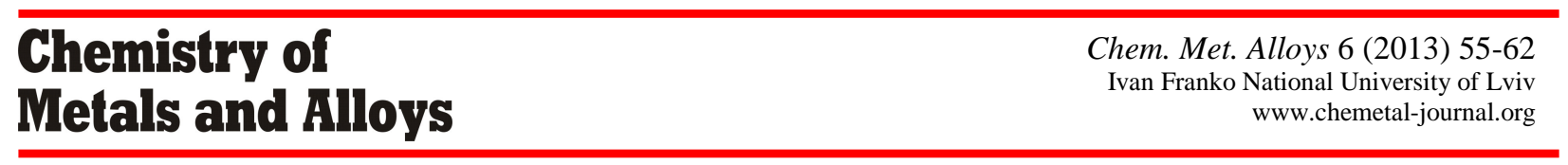

\title{
The $\mathrm{Tl}_{2} \mathrm{Se}-\mathrm{HgSe}-\mathrm{GeSe}_{2}$ system and the crystal structure of $\mathrm{Tl}_{2} \mathrm{HgGeSe}_{4}$
}

\author{
M.Yu. MOZOLYUK ${ }^{1 *}$, L.V. PISKACH ${ }^{1}$, A.O. FEDORCHUK ${ }^{2}$, I.D. OLEKSEYUK ${ }^{1}$, O.V. PARASYUK ${ }^{1}$ \\ ${ }^{1}$ Department of Inorganic and Physical Chemistry, Lesya Ukrainka Eastern European National University, \\ Volya Ave. 13, 43025 Lutsk, Ukraine \\ ${ }^{2}$ Department of Inorganic and Organic Chemistry, Lviv National University of Veterinary Medicine and \\ Biotechnologies, Pekarska St. 50, 79010 Lviv, Ukraine \\ * Corresponding author. Tel: +380 332 259846; e-mail: oliam86@mail.ru
}

Received February 14, 2013; accepted June 19, 2013; available on-line November 4, 2013

The phase equilibria in the quasi-ternary system $\mathrm{Tl}_{2} \mathrm{Se}-\mathrm{HgSe}-\mathrm{GeSe}_{2}$ were investigated by differential-thermal analysis and $\mathrm{X}$-ray diffraction. Phase diagrams of the $\mathrm{Tl}_{2} \mathrm{Se}-\mathrm{HgSe}$ and $\mathrm{Tl}_{2} \mathrm{GeSe}_{3}-\mathrm{HgSe}$ systems were constructed, as well as the isothermal section of the $\mathrm{Tl}_{2} \mathrm{Se}-\mathrm{HgSe}-\mathrm{GeSe}_{2}$ system at $520 \mathrm{~K}$. Two intermediate quaternary compounds, $\mathrm{Tl}_{2} \mathrm{HgGeSe}_{4}$ and $\mathrm{Tl}_{2} \mathrm{HgGe}_{2} \mathrm{Se}_{6}$, exist at this temperature. $\mathrm{Tl}_{2} \mathrm{HgGeSe}_{4}$ crystallizes in the non-centrosymmetric space group $I-42 m$ with the unit cell parameters $a=0.79947(4) \mathrm{nm}$, $c=0.67617(4) \mathrm{nm}$.

\section{Chalcogenides / Semiconductors / X-ray diffraction / Crystal structure}

\section{Introduction}

Quaternary chalcogenides $\mathrm{I}_{2}-\mathrm{II}-\mathrm{IV}-\mathrm{VI}_{4}$ have been extensively studied because these compounds exhibit properties that are promising for applications in nonlinear optics, detection of $\gamma$-radiation, solar energy conversion, etc. [1-6]. Available information on quaternary phases of this type that form in the quasiternary systems $A_{2}^{\mathrm{I}} X-B^{\mathrm{II}} X-D^{\mathrm{IV}} X_{2} \quad\left(A^{\mathrm{I}}=\mathrm{Cu}, \mathrm{Ag}\right.$; $B^{\mathrm{II}}=\mathrm{Zn}, \mathrm{Cd}, \mathrm{Hg}, \mathrm{Mn}, \mathrm{Pb} ; D^{\mathrm{IV}}=\mathrm{Si}, \mathrm{Ge}, \mathrm{Sn} ; X=\mathrm{S}, \mathrm{Se}$, Te) was summarized by us in [7]. Compounds form in all possible combinations of the systems with $A^{\mathrm{I}}=\mathrm{Cu}$; for the silver-containing systems, they exist only for $X=\mathrm{S}$ [1,7-12] and some systems with Se [7], but do not form in tellurium-containing systems.

The search for new quaternary compounds was extended to the thallium-containing systems $\mathrm{Tl}_{2} X-B^{\mathrm{II}} X-D^{\mathrm{IV}} X_{2}$, which are analogous to the $\mathrm{Cu}$ - and Ag-containing systems, but are sparsely investigated. The formation of the quaternary compound $\mathrm{Tl}_{2} \mathrm{PbGeS}_{4}$, which crystallizes in a monoclinic structure (space group $P 2_{1} / a$ ), is known [13]. The authors of [14] report the crystal structure, electronic structure and thermoelectric properties of several telluride compounds $\mathrm{Tl}_{2} B^{\mathrm{II}} D^{\mathrm{IV}} \mathrm{Te}_{4}\left(B^{\mathrm{II}}=\mathrm{Cd}, \mathrm{Hg}, \mathrm{Mn}\right.$; $\left.D^{\mathrm{IV}}=\mathrm{Ge}, \mathrm{Sn}\right)$. All of these compounds are isostructural and crystallize in the tetragonal space group $I-42 m$.

Here, we report an investigation of the phase equilibria in one of the above-mentioned systems, namely $\mathrm{Tl}_{2} \mathrm{Se}-\mathrm{HgSe}-\mathrm{GeSe}_{2}$, and the crystal structure of a new quaternary compound that forms in the quasi-binary section $\mathrm{Tl}_{2} \mathrm{GeSe}_{3}-\mathrm{HgSe}$ at the equimolar ratio of the components.

The compounds $\mathrm{Tl}_{2} \mathrm{Se}, \mathrm{HgSe}$ and $\mathrm{GeSe}_{2}$ melt congruently at 663 [15], 1073 [16] and $1050 \mathrm{~K}$ [17], respectively. $\mathrm{Tl}_{2} \mathrm{Se}$ crystallizes in a tetragonal structure (space group $P 4 / n c c, a=0.852 \mathrm{~nm}$, $c=1.268 \mathrm{~nm}$ ) [18]. The crystal structure of $\mathrm{HgSe}$ is cubic (space group $F-43 m, a=0.6460 \mathrm{~nm}$ ) [16]. $\mathrm{GeSe}_{2}$ has a monoclinic structure (space group $P 2_{1} / c$ ) with the lattice parameters $a=0.7016(3) \mathrm{nm}$, $b=1.6796(8) \mathrm{nm}, c=1.1831(5) \mathrm{nm}, \beta=90.65(5)^{\circ}$ [19].

The phase diagrams of the boundary quasi-binary systems are known. According to [20], the $\mathrm{Tl}_{2} \mathrm{Se}-\mathrm{HgSe}$ system features a ternary compound, $\mathrm{Hg}_{3} \mathrm{Tl}_{2} \mathrm{Se}_{4}$, which melts incongruently at $691 \mathrm{~K}$ and has a polymorphous transition at $568 \mathrm{~K}$. One of the modifications crystallizes in a monoclinic structure, space group $C 2 / c, a=1.1977(2) \mathrm{nm}$, $b=0.69264(14) \mathrm{nm}, c=1.3203(3) \mathrm{nm}, \beta=116.36(3)^{\circ}$ [21]. Three compounds were found in the $\mathrm{Tl}_{2} \mathrm{Se}-\mathrm{GeSe}_{2}$ system: $\mathrm{Tl}_{4} \mathrm{GeSe}_{4}$ and $\mathrm{Tl}_{2} \mathrm{GeSe}_{3}$ melt congruently at 661 and $706 \mathrm{~K}$, respectively, with $\mathrm{Tl}_{2} \mathrm{GeSe}_{3}$ melting at the transition point; $\mathrm{Tl}_{2} \mathrm{Ge}_{2} \mathrm{Se}_{5}$ melts incongruently at $778 \mathrm{~K} \quad$ [22]. $\mathrm{Tl}_{4} \mathrm{GeSe}_{4}$ has a monoclinic structure (space group $C 2 / c, \quad a=1.16700(2) \mathrm{nm}, \quad b=0.73170(1) \mathrm{nm}$, $\left.c=2.56030(10) \mathrm{nm}, \beta=106.54(1)^{\circ}\right)[23] . \mathrm{Tl}_{2} \mathrm{GeSe}_{3}$ crystallizes in a triclinic structure (space group $P-1$ ) with the unit cell parameters $a=1.5602 \mathrm{~nm}$, 
$b=1.5549(5) \mathrm{nm}, c=0.9052(3) \mathrm{nm}, \alpha=90.55(7)^{\mathrm{o}}$, $\beta=111.42(6)^{\circ}, \gamma=114.45(7)^{\circ}[24] . \mathrm{Tl}_{2} \mathrm{Ge}_{2} \mathrm{Se}_{5}$ also has a monoclinic structure (space group $C 2 / c$ ), with the lattice parameters $a=0.8481(2) \mathrm{nm}$, $b=0.8411(2) \mathrm{nm}, c=1.5800(5) \mathrm{nm}, \beta=107.10(3)^{\circ}$ [25]. An investigation of the $\mathrm{HgSe}-\mathrm{GeSe}_{2}$ system [26] showed the existence of the ternary compound $\mathrm{Hg}_{2} \mathrm{GeSe}_{4}$, which forms in a peritectic reaction at $893 \mathrm{~K}$ and has a polymorphous transition at $830 \mathrm{~K}$. Its low-temperature modification has a tetragonal cadmium thiogallate-type structure (space group I-4) with the lattice parameters $a=0.5672 \mathrm{~nm}$, $c=1.1322 \mathrm{~nm}$ [26] (or $a=0.56786 \mathrm{~nm}$, $c=1.12579 \mathrm{~nm} \mathrm{[27];} a=0.56741 \mathrm{~nm}, c=1.1249 \mathrm{~nm}$ [28]).

\section{Experimental}

A total of 50 samples were prepared for the investigation of the phase equilibria in the quasiternary system $\mathrm{Tl}_{2} \mathrm{Se}-\mathrm{HgSe}-\mathrm{GeSe}_{2}$. The alloys were synthesized from elementary $\mathrm{Tl}, \mathrm{Ge}, \mathrm{Se}$ (purity at least 99.99 wt.\%) and previously prepared $\mathrm{HgSe}$ (Hg 99.999 wt.\%). The synthesis was performed using the single-temperature method in evacuated quartz ampoules that were placed in a shaft-type furnace and heated to $870 \mathrm{~K}$ at the rate of $30 \mathrm{~K} / \mathrm{h}$. The melts were held at this temperature for $6 \mathrm{~h}$ with periodic vibration, and then cooled to $520 \mathrm{~K}$ at the rate of $10 \mathrm{~K} / \mathrm{h}$. The alloys were annealed at this temperature for $250 \mathrm{~h}$, and then quenched into cold water. The obtained alloys were compact, black ingots with a characteristic luster.

XRD spectra were recorded on a DRON 4-13 diffractometer, using $\mathrm{Cu} K_{\alpha}$ radiation with $\mathrm{Ni}$ filter $\left(10^{\circ} \leq 2 \theta \leq 90^{\circ}\right.$, scan step $0.05^{\circ}$ and $2 \mathrm{~s}$ exposure at each point, for phase analysis; $10^{\circ} \leq 2 \theta \leq 100^{\circ}, 0.02^{\circ}$, $28 \mathrm{~s}$ exposure, for the structure refinement). The XRD sets were processed using PDWin2 and CSD software [29].

Thermal analysis was performed using a PaulikPaulik-Erdey derivatograph, with the temperature measured by a Pt/Pt-Rh thermocouple.

\section{Results and discussion}

\subsection{Phase diagram of the $\mathrm{Tl}_{2} \mathrm{Se}-\mathrm{HgSe}$ system}

The existence of all previously known ternary compounds in the boundary systems of the $\mathrm{Tl}_{2} \mathrm{Se}-\mathrm{HgSe}-\mathrm{GeSe}_{2}$ system was confirmed.

The re-investigation of the phase diagram of the $\mathrm{Tl}_{2} \mathrm{Se}-\mathrm{HgSe}$ system confirmed the formation of the ternary compound $\mathrm{Tl}_{2} \mathrm{Hg}_{3} \mathrm{Se}_{4}$, as reported in [20]. The temperatures of the physico-chemical processes, however, were different. $\mathrm{Tl}_{2} \mathrm{Hg}_{3} \mathrm{Se}_{4}$ forms in a peritectic reaction, $\mathrm{L}+\mathrm{HgSe} \leftrightarrow \beta-\mathrm{Tl}_{2} \mathrm{Hg}_{3} \mathrm{Se}_{4}$, at $602 \mathrm{~K}$ and has a polymorphous transition, $\alpha-\mathrm{Tl}_{2} \mathrm{Hg}_{3} \mathrm{Se}_{4} \leftrightarrow$
$\beta-\mathrm{Tl}_{2} \mathrm{Hg}_{3} \mathrm{Se}_{4}$, at $540 \mathrm{~K}$. A eutectic point occurs at $28 \mathrm{~mol} . \% \mathrm{HgSe}$ and $560 \mathrm{~K}$. The constructed phase diagram of the system is shown in Fig. 1.

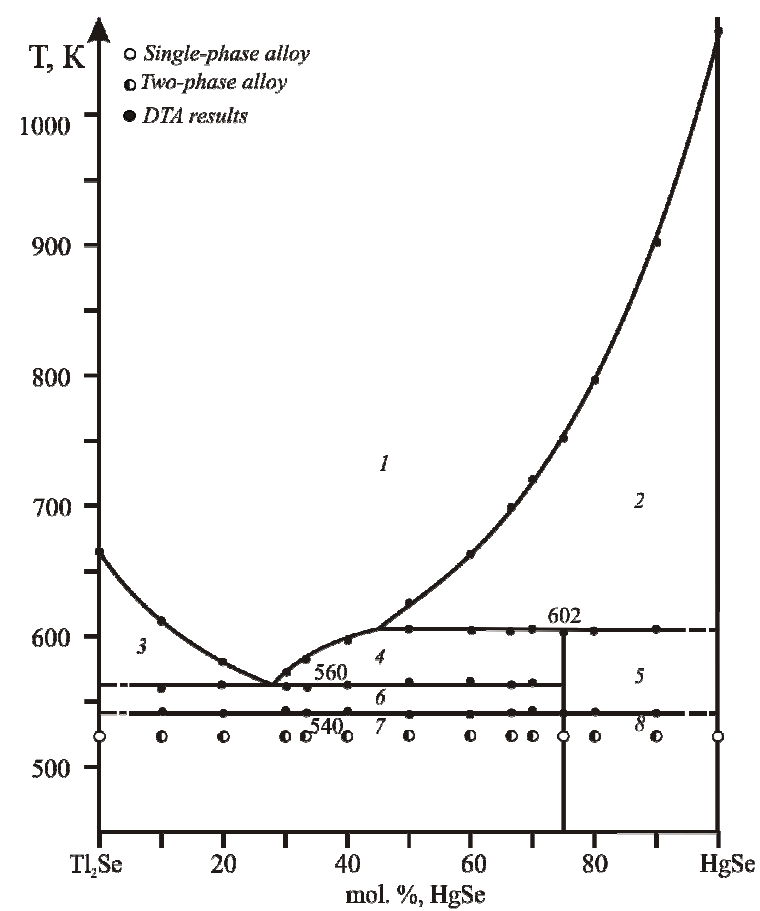

Fig. 1 Phase diagram of the $\mathrm{Tl}_{2} \mathrm{Se}-\mathrm{HgSe}$ system:

$1-\mathrm{L} ; 2-\mathrm{L}+\mathrm{HgSe} ; 3-\mathrm{L}+\mathrm{Tl}_{2} \mathrm{Se}$;

$4-\mathrm{L}+\beta-\mathrm{Tl}_{2} \mathrm{Hg}_{3} \mathrm{Se}_{4} ; 5-\beta-\mathrm{Tl}_{2} \mathrm{Hg}_{3} \mathrm{Se}_{4}+\mathrm{HgSe}$;

$6-\mathrm{Tl}_{2} \mathrm{Se}+\beta-\mathrm{Tl}_{2} \mathrm{Hg}_{3} \mathrm{Se}_{4}$;

$7-\alpha-\mathrm{Tl}_{2} \mathrm{Hg}_{3} \mathrm{Se}_{4}+\mathrm{Tl}_{2} \mathrm{Se} ; 8-\alpha-\mathrm{Tl}_{2} \mathrm{Hg}_{3} \mathrm{Se}_{4}+\mathrm{HgSe}$.

\subsection{Phase diagram of the $\mathrm{Tl}_{2} \mathrm{GeSe}_{3}-\mathrm{HgSe}$ system}

The $\mathrm{Tl}_{2} \mathrm{GeSe}_{3}-\mathrm{HgSe}$ system is a quasi-binary section, which triangulates the quasi-ternary system $\mathrm{Tl}_{2} \mathrm{Se}-\mathrm{HgSe}-\mathrm{GeSe}_{2}$ into two sub-systems, $\mathrm{Tl}_{2} \mathrm{Se}-\mathrm{Tl}_{2} \mathrm{GeSe}_{3}-\mathrm{HgSe}$ and $\mathrm{GeSe}_{2}-\mathrm{Tl}_{2} \mathrm{GeSe}_{3}-\mathrm{HgSe}$. The investigated $\mathrm{Tl}_{2} \mathrm{GeSe}_{3}-\mathrm{HgSe}$ section features one quaternary compound, $\mathrm{Tl}_{2} \mathrm{HgGeSe}_{4}$, which melts congruently at $762 \mathrm{~K}$ (Fig. 2). The interactions in the partial systems $\mathrm{Tl}_{2} \mathrm{GeSe}_{3}-\mathrm{Tl}_{2} \mathrm{HgGeSe}_{4}$ and $\mathrm{Tl}_{2} \mathrm{HgGeSe}_{4}-\mathrm{HgSe}$ are eutectic in nature. The curves of primary crystallization cross at eutectic points at 14 and 60 mol.\% $\mathrm{HgSe}$ at 663 and $740 \mathrm{~K}$, respectively. The solid solution ranges of the section components are smaller than 2 mol. $\% \mathrm{Tl}_{2} \mathrm{GeSe}_{3}$ and 5 mol. $\% \mathrm{HgSe}$ at the annealing temperature. Representative diffraction patterns of alloys from the investigated system confirm the DTA results, and are presented in Fig. 3. The diffraction patterns of the alloys with 0 , 50, $100 \mathrm{~mol} \% \mathrm{HgSe}$ content correspond to the quaternary and the two boundary compounds. The diffraction patterns of the intermediate alloys with 10 , $30,60,80,95 \mathrm{~mol} \% \mathrm{HgSe}$ content contain two sets of reflections of the system components with gradually changing intensities. 


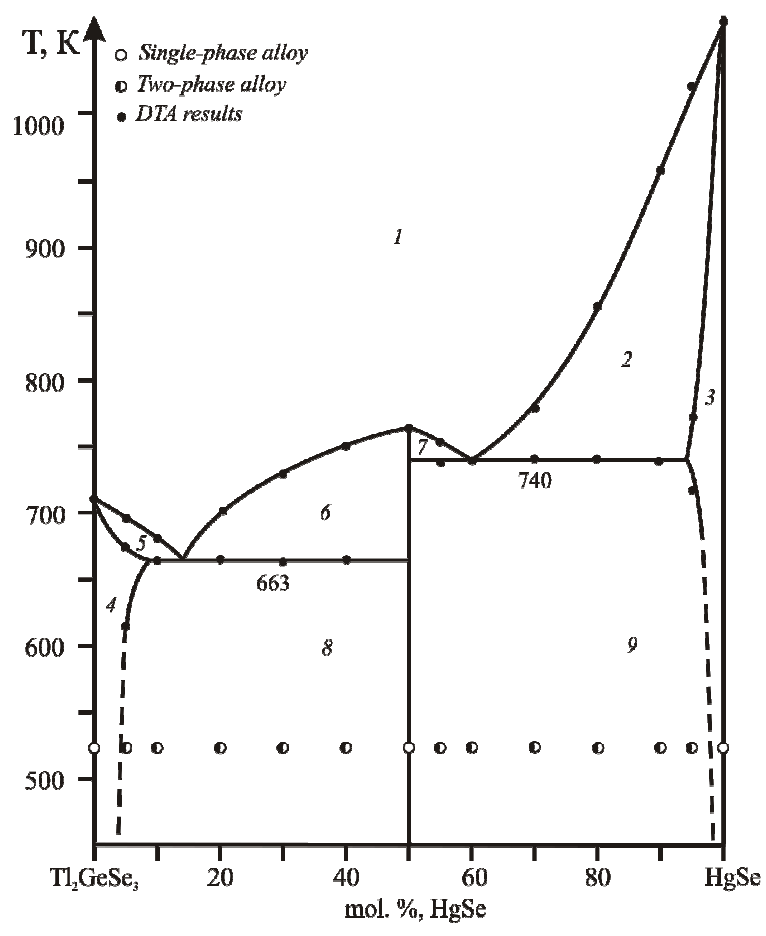

Fig. 2 Phase diagram of the quasi-binary system $\mathrm{Tl}_{2} \mathrm{GeSe}_{3}-\mathrm{HgSe}$ :

1 - L; 2 - L+HgSe; 3 - HgSe; $4-\mathrm{Tl}_{2} \mathrm{GeSe}_{3}$;

$5-\mathrm{L}+\mathrm{Tl}_{2} \mathrm{GeSe}_{3} ; 6,7-\mathrm{L}+\mathrm{Tl}_{2} \mathrm{HgGeSe}_{4}$;

$8-\mathrm{Tl}_{2} \mathrm{GeSe}_{3}+\mathrm{Tl}_{2} \mathrm{HgGeSe}_{4}$;

$9-\mathrm{HgSe}+\mathrm{Tl}_{2} \mathrm{HgGeSe}_{4}$.

\subsection{Isothermal section of the $\mathrm{Tl}_{2} \mathrm{Se}-\mathrm{HgSe}-\mathrm{GeSe}_{2}$} system at $520 \mathrm{~K}$

The isothermal section of the quasi-ternary $\mathrm{Tl}_{2} \mathrm{Se}-\mathrm{HgSe}-\mathrm{GeSe}_{2}$ system at $520 \mathrm{~K}$ was constructed from the results of the XRD phase analysis (Fig. 4).
The sections $\mathrm{Tl}_{2} \mathrm{GeSe}_{3}-\mathrm{HgSe}$ and $\mathrm{Tl}_{2} \mathrm{HgGeSe}_{4}-\mathrm{GeSe}_{2}$ are most interesting, as they feature quaternary phases. The former is described in detail above, and the determination of the crystal structure of $\mathrm{Tl}_{2} \mathrm{HgGeSe}_{4}$ is presented below (see Sect. 3.4). A quaternary phase with unknown structure was found in the $\mathrm{Tl}_{2} \mathrm{HgGeSe}_{4}-\mathrm{GeSe}_{2}$ section. The best diffraction pattern of this phase was obtained for the alloy with the composition $25 \mathrm{~mol} \% \mathrm{Tl}_{2} \mathrm{Se}, 25 \mathrm{~mol} \% \mathrm{HgSe}$, $50 \mathrm{~mol} . \% \mathrm{GeSe}_{2}$, which corresponds to the formula $\mathrm{Tl}_{2} \mathrm{HgGe}_{2} \mathrm{Se}_{6}$. Its crystal structure is currently under investigation.

\subsection{Crystal structure of the quaternary compound $\mathrm{Tl}_{2} \mathrm{HgGeSe}_{4}$}

The crystal structure of $\mathrm{Tl}_{2} \mathrm{HgGeSe}_{4}$ was determined by X-ray powder diffraction. The experimental conditions and the crystallographic parameters of the $\mathrm{Tl}_{2} \mathrm{HgGeSe}_{4}$ structure are listed in Table 1. The structure was refined by the Rietveld method, using $\mathrm{Tl}_{2} \mathrm{HgGeTe}_{4}$ as starting model [14]. The original article reports the $\mathrm{Tl}_{2} \mathrm{HgGeTe}_{4}$ structure as a superstructure of $\mathrm{Tl}_{2} \mathrm{Se}_{2}$ in the non-centrosymmetric space group $I-42 m$. Experimental and theoretical diffraction patterns of $\mathrm{Tl}_{2} \mathrm{HgGeSe}_{4}$ and their difference are plotted in Fig. 5.

A new approach to the representation of the crystal structure was proposed in [30], focusing on the stacking of hexagonal (wurtzite type) and cubic (sphalerite type) layers. Using this approach, the second coordination surrounding (SCS) in $\mathrm{Tl}_{2} \mathrm{HgGeSe}_{4}$ can be presented as a defective $(-1)$ hexagonal analog of a cuboctahedron, obtained by the substitution of one selenium atom for two. The metal atoms $(\mathrm{Tl}, \mathrm{Hg}$ ) form a trigonal-prismatic surrounding around the selenium atoms, as shown in Fig. 6. The location of the chalcogen atoms within the SCS

Table 1 Investigation of the $\mathrm{Tl}_{2} \mathrm{HgGeSe}_{4}$ crystal structure.

\begin{tabular}{l|l}
\hline Space group & $I-42 m$ \\
$a, \mathrm{~nm}$ & $0.79947(4)$ \\
$c, \mathrm{~nm}$ & $0.67617(4)$ \\
$V, \mathrm{~nm}^{3}$ & $0.43217(7)$ \\
Number of atoms per cell & 16 \\
Radiation & $\mathrm{Cu} K_{\alpha}$ \\
wavelength, nm & 0.154185 \\
Diffractometer & DRON $4-13$ \\
Calculation method & Full profile \\
Calculated density $D_{\mathrm{x}}, \mathrm{g} \cdot \mathrm{cm}^{-3}$ & $7.716(1)$ \\
Absorption coefficient $\mu, \mathrm{cm}^{-1}$ & 1313.73 \\
Number of atom sites & 4 \\
Number of refined parameters & 16 \\
$2 \theta,{ }^{\circ}$, and sin $\theta / \lambda_{\text {max }}, \mathrm{nm}^{-1}$ & 119.66 and 5.61 \\
Texture axis and parameter & {$[001]$ and 1.6513} \\
$R_{I}$ and $R_{\mathrm{p}}$ & 0.0677 and 0.1185 \\
\hline
\end{tabular}




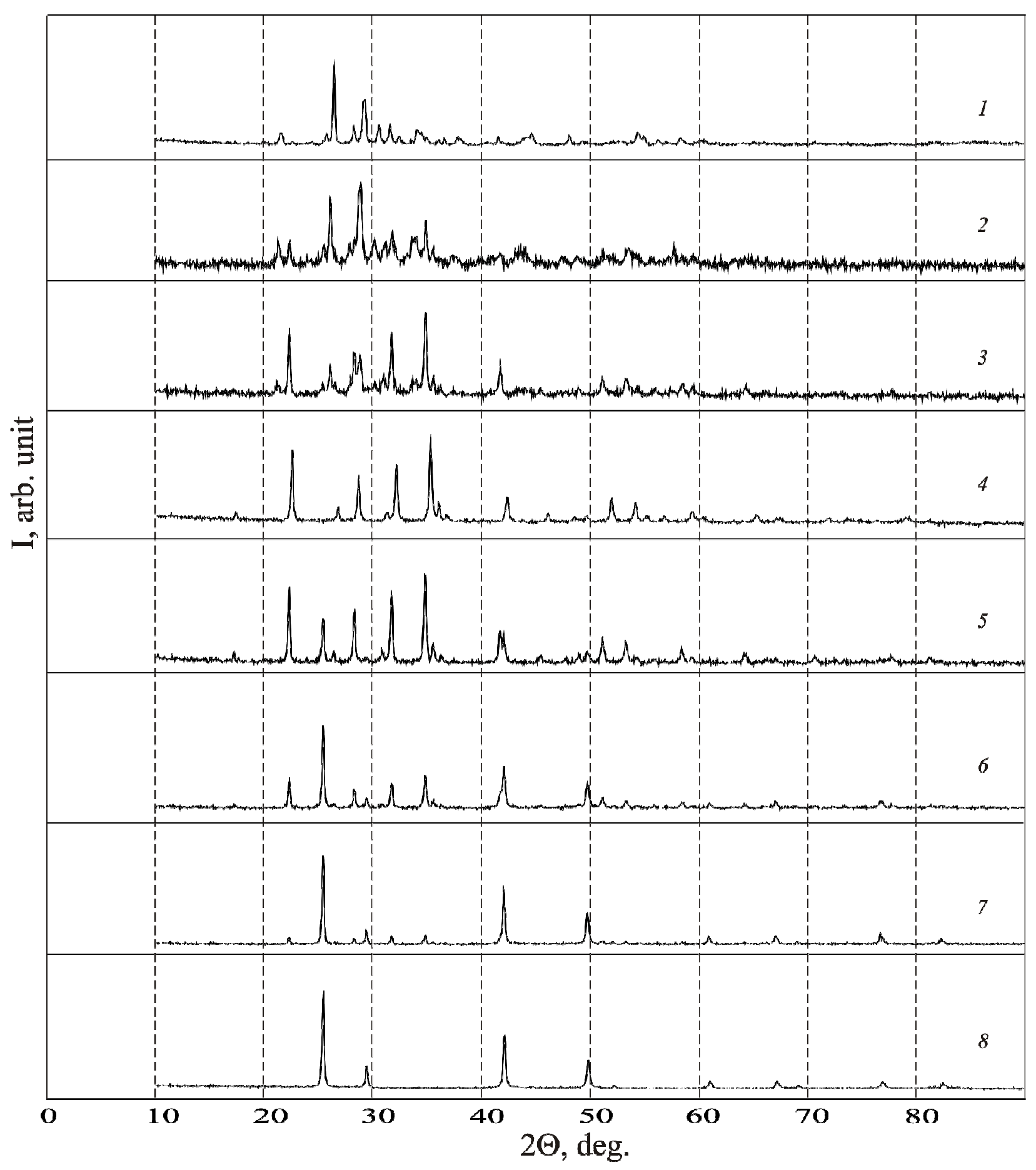

Fig. 3 Diffraction patterns of $\mathrm{Tl}_{2} \mathrm{GeSe}_{3}-\mathrm{HgSe}$ alloys annealed at $520 \mathrm{~K}$ (mol.\% HgSe): $1-0 ; 2-10 ; 3-30$; $4-50 ; 5-60 ; 6-80 ; 7-95 ; 8-100$.

is similar to that in the $\mathrm{Tl}_{2} \mathrm{Se}_{2}$ structure, or its superstructure, $\mathrm{TlInSe}_{2}$ [31], which have the same anion sub-lattice, where the atoms of mono- and trivalent thallium (or thallium and indium in TIInSe ${ }_{2}$ ) occupy analogous sites .

The $\mathrm{Tl}_{2} \mathrm{HgGeSe}_{4}$ structure features germaniumcentered tetrahedra of selenium atoms at the points of a body-centered cubic sub-lattice. Six cations form octahedra around these tetrahedra, as shown in Fig. 7.

No strongly pronounced layers are seen in the structure, but a 3D framework may be pointed out, which can be described as an intersection of layers of chalcogen atoms (Fig. 8). The shortest distances between selenium atoms are shown, and the mercury 


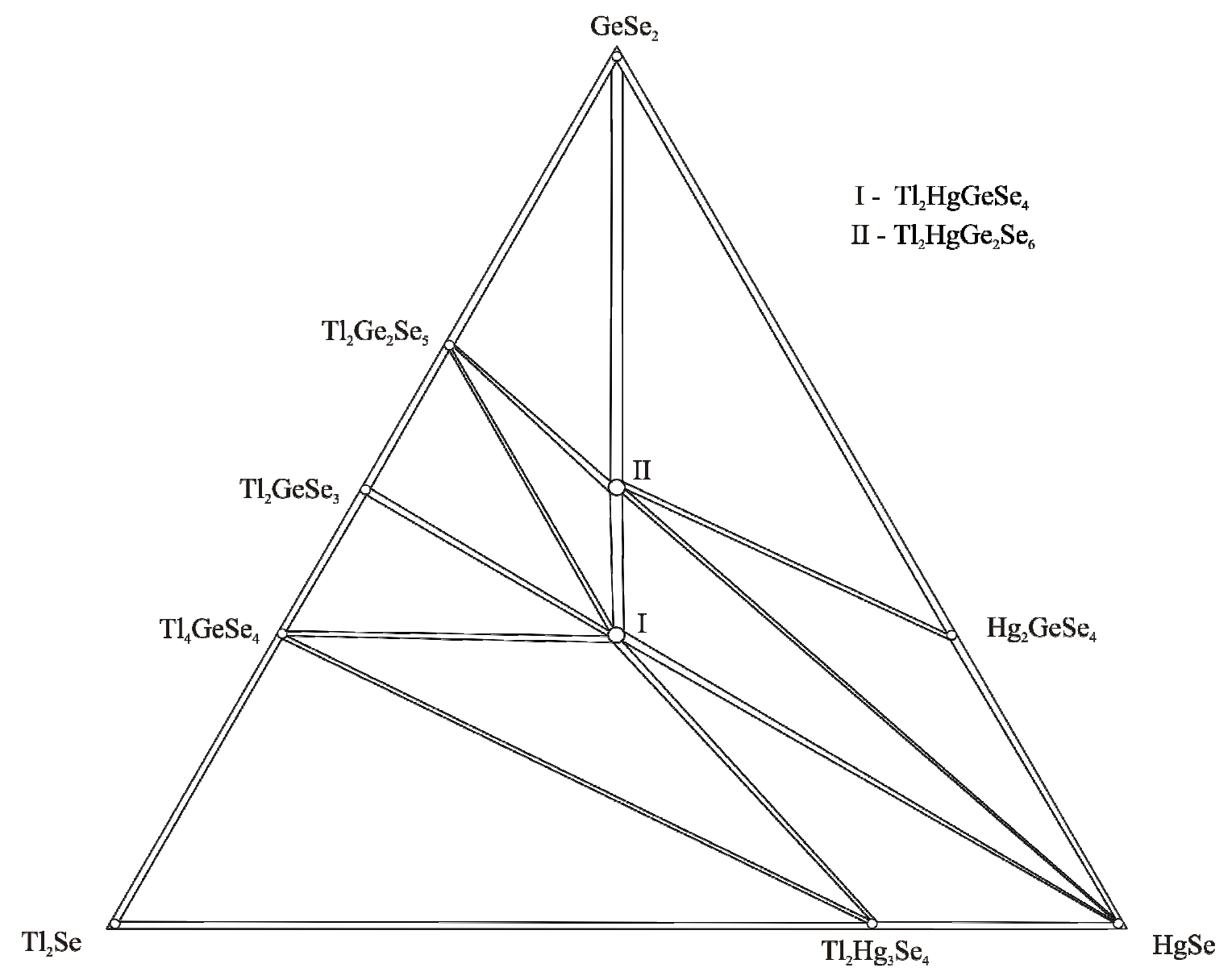

Fig. 4 Isothermal section of the $\mathrm{Tl}_{2} \mathrm{Se}-\mathrm{HgSe}-\mathrm{GeSe}_{2}$ system at $520 \mathrm{~K}$.

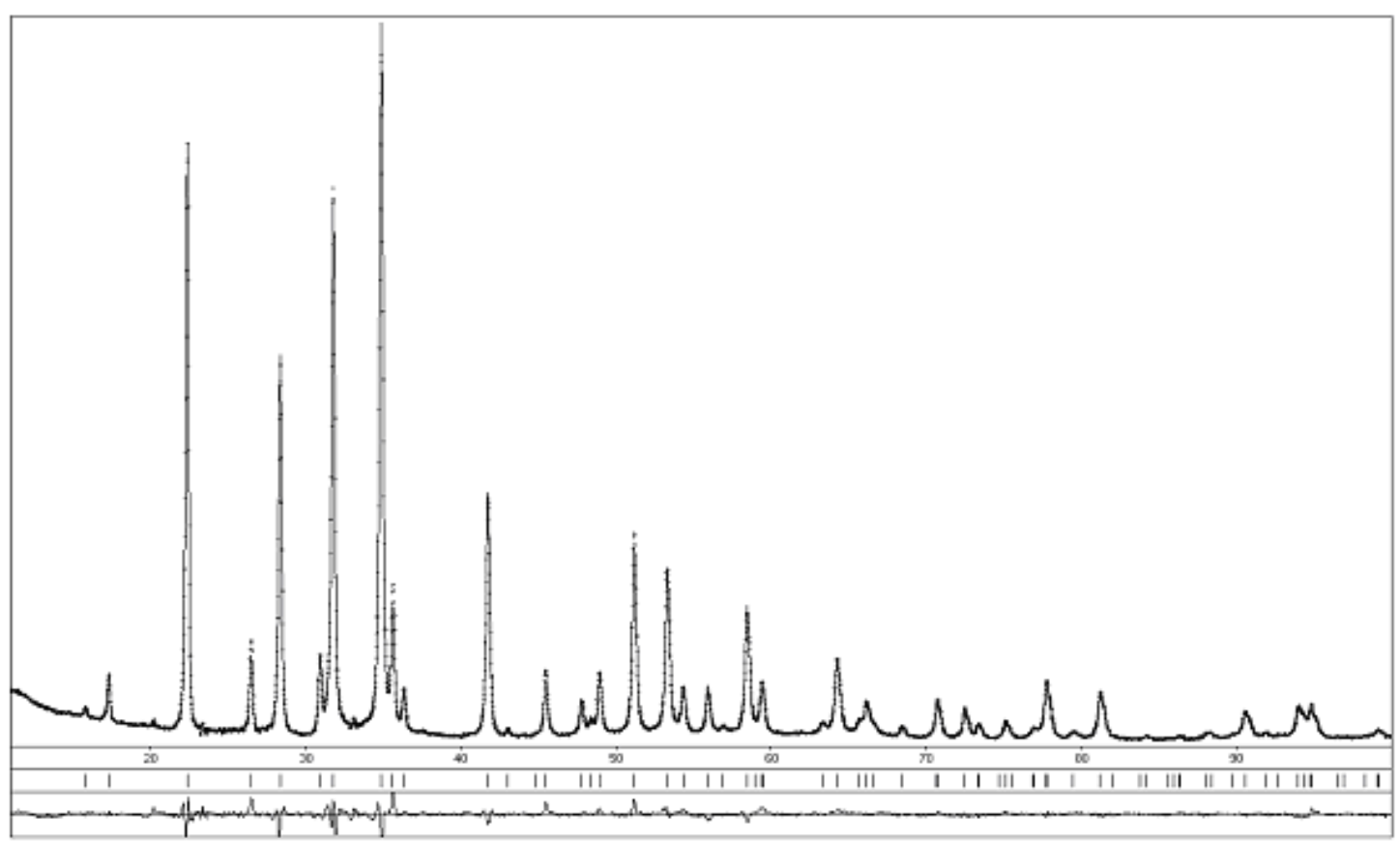

Fig. 5 Experimental and theoretical diffraction patterns of $\mathrm{Tl}_{2} \mathrm{HgGeSe}_{4}$, and their difference. 


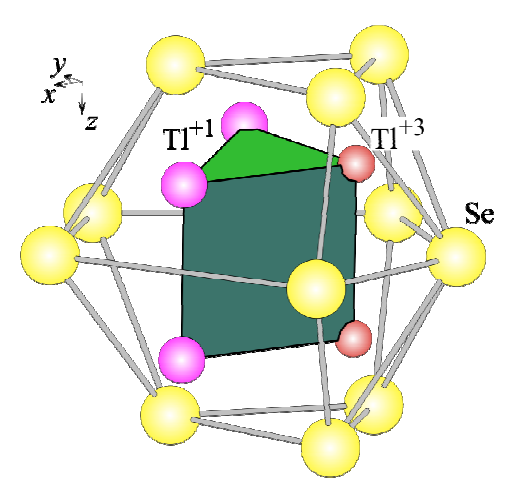

$\mathrm{Tl}_{2} \mathrm{Se}_{2}$

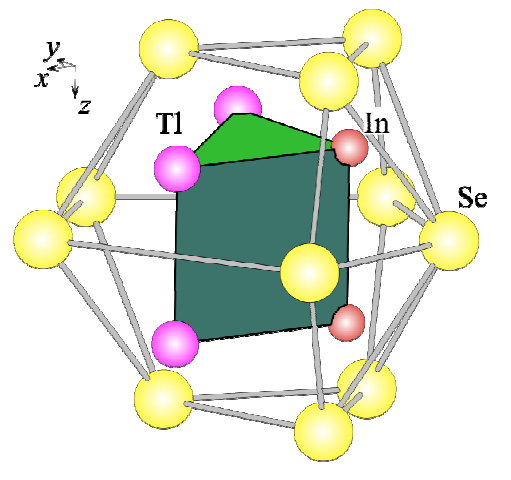

$\mathrm{TlInSe}_{2}$

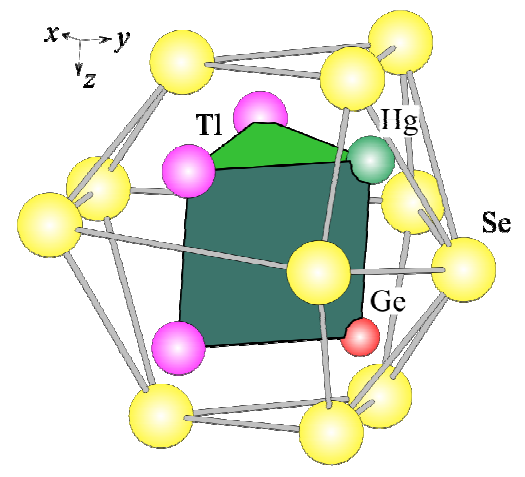

$\mathrm{Tl}_{2} \mathrm{HgGeSe}_{4}$

Fig. 6 Location of the metal atoms within the defect Se sub-lattice in the structures of $\mathrm{Tl}_{2} \mathrm{Se}_{2}, \mathrm{TlInSe}_{2}$ and $\mathrm{Tl}_{2} \mathrm{HgGeSe}_{4}$.

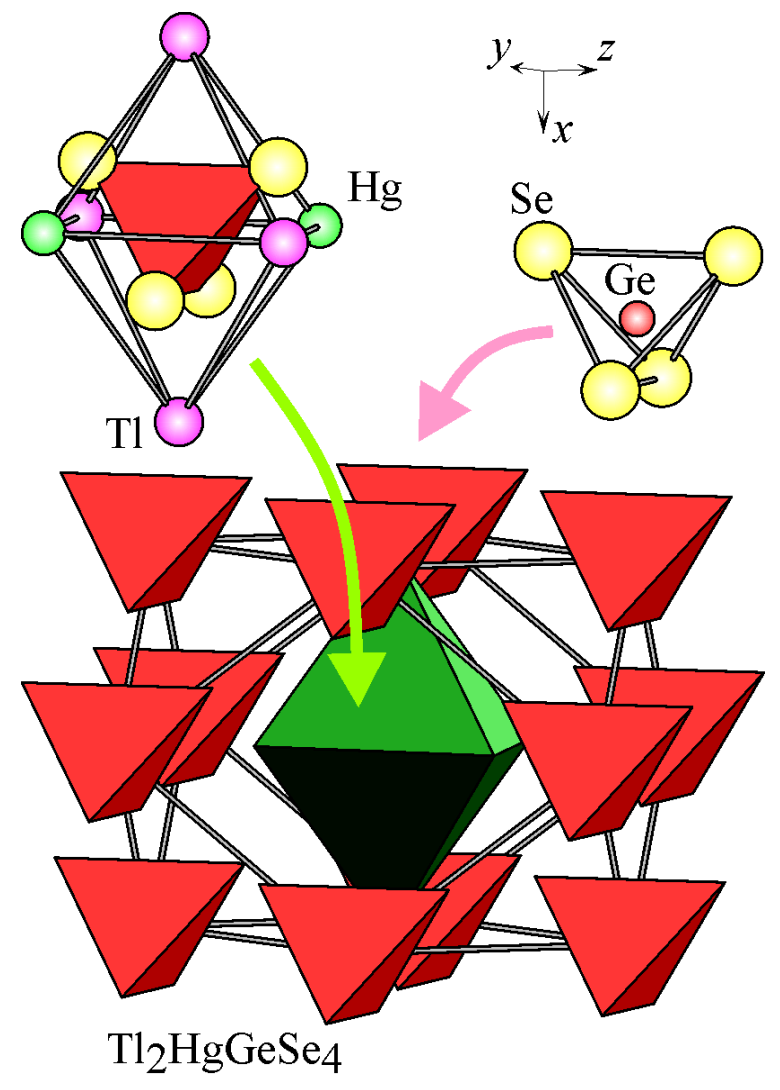

Fig. 7 Location of metal atoms within the cubic anionic sub-lattice formed by germaniumcentered tetrahedra of selenium atoms in the $\mathrm{Tl}_{2} \mathrm{HgGeSe}_{4}$ structure.

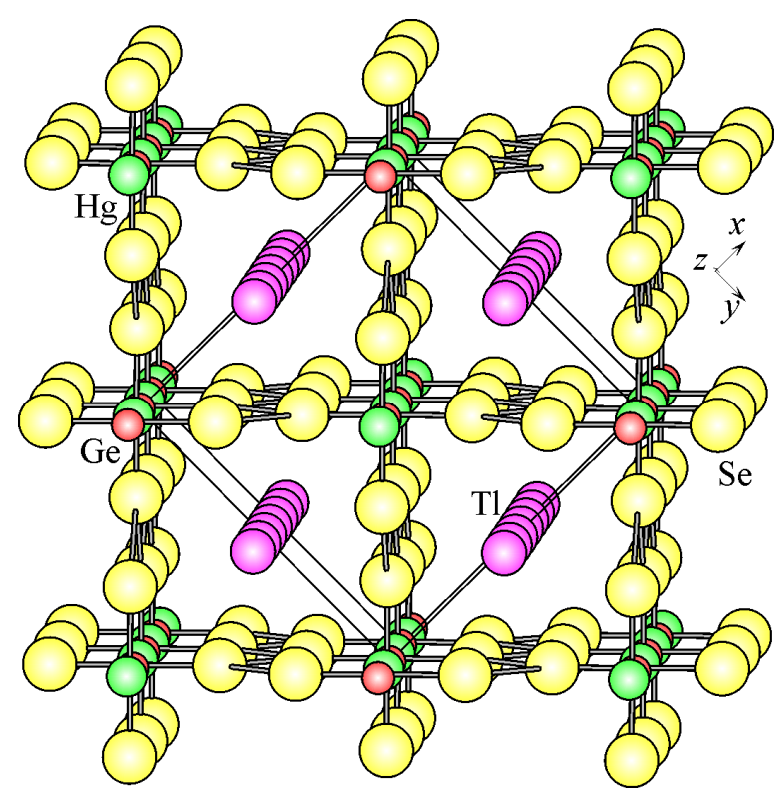

Fig. 8 Shortest $\mathrm{Se}-\mathrm{Se}$ distances in the $\mathrm{Tl}_{2} \mathrm{HgGeSe}_{4}$ structure.

and germanium atoms are located in the voids at the intersections of the nets. The thallium atoms are located in the channels of the 3D framework.

The atom coordinates and isotropic displacement parameters are presented in Table 2, the interatomic distances are listed in Table 3. According to the obtained results, the refined formula of the quaternary compound $\mathrm{Tl}_{2} \mathrm{HgGeSe}_{4}$ corresponds to the stoichiometric one. 
Table 2 Atom coordinates, site occupations and isotropic displacement parameters in the structure of $\mathrm{Tl}_{2} \mathrm{HgGeSe}_{4}$, space group I-42m.

\begin{tabular}{c|c|c|c|c|c|c}
\hline Atom & $\begin{array}{c}\text { Wyckoff } \\
\text { position }\end{array}$ & $x$ & $y$ & $z$ & $\begin{array}{c}\text { Site } \\
\text { occupation }\end{array}$ & $B_{\text {iso }} \times 10^{2}, \mathrm{~nm}^{2}$ \\
\hline $\mathrm{Hg}$ & $2 b$ & 0 & 0 & $1 / 2$ & 1.0 & $2.46(6)$ \\
$\mathrm{Tl}$ & $4 c$ & 0 & $1 / 2$ & 0 & 1.0 & $2.07(6)$ \\
$\mathrm{Ge}$ & $2 a$ & 0 & 0 & 0 & 1.0 & $2.41(2)$ \\
$\mathrm{Se}$ & $8 i$ & $0.1693(2)$ & $0.1693(2)$ & $0.2189(5)$ & 1.0 & $1.17(6)$ \\
\hline
\end{tabular}

Table 3 Interatomic distances in the $\mathrm{Tl}_{2} \mathrm{HgGeSe}_{4}$ structure.

\begin{tabular}{l|l}
\hline $\mathrm{Tl}_{2} \mathrm{HgGeSe}_{4}$ & Distance, $\mathrm{nm}$ \\
\hline $\mathrm{Hg}-\mathrm{Se}$ & $0.2688(3) \times 4$ \\
$\mathrm{Tl}-\mathrm{Se}$ & $0.3323(2) \times 4$ \\
& $0.3523(2) \times 4$ \\
$\mathrm{Ge}-\mathrm{Se}$ & $0.2420(2) \times 4$ \\
\hline
\end{tabular}

The Tl-Se distances (Table 3) show good agreement with the sum of the ionic radii

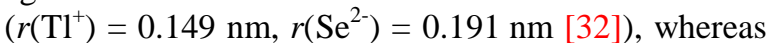
the distances $\mathrm{Hg}-\mathrm{Se}$ and $\mathrm{Ge}-\mathrm{Se}$ are somewhat shorter than the sum of the ionic radii $\left(r\left(\mathrm{Hg}^{2+}\right)=0.112 \mathrm{~nm}\right.$, $r\left(\mathrm{Ge}^{4+}\right)=0.272 \mathrm{~nm}$ [32]). Commonly, one of the reasons for such contraction is partially covalent bonding between the atoms. The Tl-Se distances $(0.323(2) \mathrm{nm}$ and $0.3523(2) \mathrm{nm})$ are commensurate with those in the ' $\mathrm{Tl}_{3} \mathrm{In}_{3} \mathrm{SnSe}_{8}$ ' structure [33]. The interatomic distances $\mathrm{Hg}-\mathrm{Se}$ are close to those in $\mathrm{Hg}_{4} \mathrm{SiSe}_{6} \quad(0.2501-0.2932 \mathrm{~nm})$ [34] or $\mathrm{Hg}_{2} \mathrm{SnSe}_{4}$ $(0.2636-0.2720 \mathrm{~nm})$ [35]. The Ge-Se distances correlate well with those in $\mathrm{Tl}_{4} \mathrm{GeSe}_{4}$ $(0.250-0.256 \mathrm{~nm})$ [24], $\mathrm{Tl}_{2} \mathrm{GeSe}_{3} \quad(0.229-0.260 \mathrm{~nm})$ [25], and $\mathrm{Tl}_{2} \mathrm{Ge}_{2} \mathrm{Se}_{5}(0.234-0.258 \mathrm{~nm})$ [23].

\section{Conclusions}

The phase equilibria in the $\mathrm{Tl}_{2} \mathrm{Se}-\mathrm{HgSe}-\mathrm{GeSe}_{2}$ system were investigated, and two intermediate quaternary phases were found. The crystal structure of the compound of the equimolar composition $\mathrm{Tl}_{2} \mathrm{HgGeSe}_{4}$ was determined by X-ray powder diffraction (space group $I-42 m$ ).

\section{References}

[1] C.D. Brunetta, B. Karuppannan, K.A. Rosmus, J.A. Aitken, J. Alloys Compd. 516 (2012) 65-72.

[2] T. Bernet, M. Zabel, A. Pfitzner, J. Solid State Chem. 179 (2006) 849-854.

[3] W. Zalewski, R. Bacewicz, J. Antonowicz, A. Pietnoczka, T.L. Evstigneyeva, S. Schour, J. Alloys Compd. 492 (2010) 35-38.

[4] A. Assoud, N. Soheilia, H. Kleinke, Chem. Mater. 17 (2005) 2255-2261.
[5] M. Quintero, A. Barreto, P. Grima, R. Tovar, E. Quintero, G. Sanches Porras, J. Ruiz, J.C. Walley, G. Lamarche, A.-M. Lamarche, Mater. Res. Bull. 34 (1999) 2263-2270.

[6] D. Caldera, M. Quintero, M. Marocoima, E. Quintero, P. Grima, N. Marchan, E. Moreno, P. Bacaranda, G.E. Delgado, A.E. Mora, J.M. Bricenno, J.L. Fernandez, J. Alloys Compd. 457 (2008) 221-224.

[7] O.V. Parasyuk, L.V. Piskach, Ya.E. Romanyuk, I.D. Olekseyuk, V.I. Zaremba, V.I. Pekhnyo, J. Alloys Compd. 397 (2005) 85-94.

[8] O.V. Parasyuk, L.V. Piskach, I.D. Olekseyuk, V.I. Pekhnyo, J. Alloys Compd. 397 (2005) 95-98.

[9] O.V. Parasyuk, I.D. Olekseyuk, L.V. Piskach, S.V. Volkov, V.I. Pekhnyo, J. Alloys Compd. 399 (2005) 173-177.

[10] O.V. Parasyuk, S.I. Chykhrij, V.V. Bozhko, L.V. Piskach, M.S. Bogdanyuk, I.D. Olekseyuk, L.V. Bulatetska, V. I. Pekhnyo, J. Alloys Compd. 399 (2005) 32-37.

[11] O.V. Parasyuk, L.D. Gulay, L.V. Piskach, O.P. Gagalovska, J. Alloys Compd. 336 (2002) 213-217.

[12] O.V. Parasyuk, A.O. Fedorchuk, Yu.M. Kogut, L.V. Piskach, I.D. Olekseyuk, J. Alloys Compd. 500 (2010) 26-29.

[13] G. Eulenberger, Z. Naturforsch. B 35 (1980) 335-339.

[14] M.A. McGuire, Th.J. Scheidemantel, J.V. Badding, F.J. DiSalvo, Chem. Mater. 17 (2005) 6186-6191.

[15] Ye.Yu. Turkina, G.M. Orlova, Zh. Neorg. Khim. 28 (1983) 1351-1353.

[16] N.K. Abrikosov, V.F. Bakina, L.V. Poretskaya, Semiconductor Chalcogenides and Their Alloys, Nauka, Moscow, 1975. 
[17] D.I. Bletzkan, Crystalline and Glassy Chalcogenides of Si, Ge, Sn and Their Alloys, Zakarpattia, Uzhgorod, 2004. (in Ukrainian).

[18] Stasova M.M., Kristallografiya 3 (1950) 141-147.

[19] Dittmar G., Schafer H., Acta Crystallogr. B 32 (1976) 2726-2728.

[20] M.M. Asadov, M.B. Babanly, A.A. Kuliev, Zh. Neorg. Khim. 27 (1982) 3173-3178.

[21] S. Johnsen, S.C. Peter, S.L. Nguyen, J.-H. Song, H. Jin, A.J. Freeman, M.G. Kanatzidis, Chem. Mater. 23 (2011) 4375-4383.

[22] O.S. Glukh, Ph.D. Thesis, Uzhgorod National Univ., 2007.

[23] O.S. Glukh, M.Yu. Sabov, I.E. Barchij, V.V. Pavlyuk, B. Marciniak, Chem. Met. Alloys 2 (2009) 10-14.

[24] G. Eulenberger, Monatsh. Chem. 113 (1982) 859-867.

[25] G. Eulenberger, Z. Naturforsch. B 33 (1978) 521-523.

[26] S.F. Motria, Yu.V. Voroshilov, M.V. Potoriy, E.E. Semrad, Ukr. Khim. Zh. 52 (1986) 807-809.
[27] O.V. Parasyuk, L.D. Gulay, Ya.E. Romanyuk, I.D. Olekseyuk, L.V. Piskach, J. Alloys Compd. 351 (2003) 135-144.

[28] Y. Dong, S. Kim, H. Yun, Acta Crystallogr. E 61 (2005) i9-i11.

[29] L.G. Akselrud, P.Yu. Zavalij, Yu.N. Grin', V.K. Pecharski, B. Baumgarther, E. Wölfel, Mater. Sci. Forum 133-136 (1993) 335-342.

[30] A.O. Fedorchuk, O.V. Parasyuk, I.V. Kityk, Mater. Chem. Phys. 139 (2013) 92-99.

[31] D. Mueller, G. Eulenberger, H. Hahn, Z. Anorg. Allg. Chem. 398 (1973) 207-222.

[32] A.F. Holleman, E. Wiberg, Lehrbuch der Anorganischen Chemie, Walter de Gruyter, Berlin, 1995.

[33] M.Yu. Mozolyuk, L.V. Piskach, A.O. Fedorchuk, I.V. Kityk, I.D. Olekseyuk, O.V. Parasyuk, J. Alloys Compd. 509 (2011) 2693-2696.

[34] L.D. Gulay, I.D. Olekseyuk, O.V. Parasyuk, J. Alloys Compd. 347 (2002) 115-120.

[35] L.D. Gulay, O.V. Parasyuk, J. Alloys Compd. 337(1-2) (2002) 94-98. 